\title{
The possibility of using Lake Rawa Pening as a source of drinking water
}

\author{
Agatha PIRANTI ${ }^{1) A B C D E F} \bowtie$, Gentur WALUYO ${ }^{2) A B}$, Diana R.U.S. RAHAYU ${ }^{3) \text { B }}$
}

\author{
Jenderal Soedirman University, Dr Soeparno Street, 53122, Purwokerto, Indonesia \\ 1) orcid.org/0000-0001-9795-8765; e-mail: agatha.piranti@gmail.com \\ 2) orcid.org/0000-0002-8012-2264; e-mail: gentur.geologi1960@gmail.com \\ 3) orcid.org/0000-0002-0052-2541; e-mail: dianaretna01@gmail.com
}

For citation: Piranti A., Waluyo G., Rahayu D.R.U.S. 2019. The possibility of using Lake Rawa Pening as a source of drinking water. Journal of Water and Land Development. No. 41 (IV-VI) p. 111-119. DOI: 10.2478/jwld-2019-0034.

\begin{abstract}
The water of Lake Rawa Pening is used as a source of drinking water. Indonesian Government Regulation Number 82 of 2001 on Management of Water Quality and Water Pollution Control stated that the water quality of Lake Rawa Pening should meet the quality standard of first grade and be categorized as no polluted water. The purpose of this research was to assess the water quality based on Indonesian regulation and to assess water quality based on international regulations. The quality of water was assessed using a survey method in 7 sites of the Lake Rawa Pening 3 times for 3 months. Parameters measured were all the water quality parameters required in accordance with Government Regulation No. 82 of 2001 . The results indicated that there were 13 values that exceeded the water quality standard of first grade. These exceeded parameters were total suspended solids (TSS), biological oxygen demand (BOD), chemical oxygen demand (COD), orthophosphate $\left(\mathrm{PO}_{4}\right), \mathrm{NO}_{3}, \mathrm{As}, \mathrm{Se}, \mathrm{Cd}, \mathrm{Mn}, \mathrm{Cu}, \mathrm{Pb}, \mathrm{H}_{2} \mathrm{~S}$, faecal coliform, and total coliform. Water quality status of Lake Rawa Pening was categorized as heavily polluted. The water quality of Lake Rawa Pening should be improved by reducing the pollutants entering the lake by restriction of human activities causing lake pollution.
\end{abstract}

Key words: drinking water, Lake Rawa Pening, Storet index, water quality standard

\section{INTRODUCTION}

Lake Rawa Pening is a natural lake located in Semarang regency, Central Java, Indonesia. The surface area of the lake is 2,770 ha with a maximum water capacity of $65 \cdot 10^{6} \mathrm{~m}^{3}$ and a minimum capacity of $25 \cdot 10^{6} \mathrm{~m}^{3}$ with the depth were between $3.87-18 \mathrm{~m}$. The Lake Rawa Pening is designated primarily to provide irrigation, recreational facilities, hydropower generation, fisheries and aquaculture using floating net. At the moment Lake Rawa Pening has severe eutrophication problems which are characterized by bloom of water hyacinth (Eichornia crassipes) which covers around $70 \%$ of the lake surface [SOEPROBOWATI, SUEDY 2010]. This condition resulted in oxygen depletion, increased TSS and total phosphorus [PIRANTI et al. 2018]. However, recently the Lake Rawa Pening water is being also used as a source of drinking water. Clean drinking water is recognised as a fundamental right of human beings. Therefore, in many parts of the world put the water quality control for the top-priority policy agenda [WHO 2011]. Recently, the water used in household is commonly defined as a source for domestic purposes. This water is processed to be safely consumed as drinking water and other purposes. Based on ISO 6773: 2008 on Specifications Unit Package Water Treatment Plant and ISO 6774: 2008 on Procedures for the Planning Unit Package Water Treatment Plant, the definition of source of drinking water is water which comes from water surface, ground water basin and or rain water that comply with certain quality standards as source for drinking water [SNI 2008]. At this time, source of water comes from surface water (rivers, lakes, reservoirs, etc.) is still the choice of piped water treatment plant. Although the terms of this water quality are not good, but in terms of quantity and continuity are 
still available in large quantities compared with three other sources of water. The issue is the quality of surface water is now to be decreasing, both for their liquid waste in the form of domestic waste and industrial waste, and garbage. Water quality standards that exist in Indonesia today based on Minister of Health Decree No. 416 in 1990 on Conditions - Terms and Water Quality Monitoring and Government Regulation Number 82 of 2001 on the Management of Water Quality and Water Pollution Control. Based on those regulations, the water that used as a source of drinking water should meet three requirements: physical, chemical and bacteriological. The physical requirements are including colourless, tasteless, and odourless. Chemical requirements should not contain toxic, mineral substances or certain chemical substances in an amount beyond the specified limits of standards. Drinking water should not contain bacteria - bacteria disease (pathogens) altogether and should not contain groups of Coli bacteria exceed the limits of one Coli per $100 \mathrm{~cm}^{3}$ of water.

Based on Government Regulation Number of 82 of 2001 on the Management of Water Quality and Water Pollution Control, if the Lake Rawa Pening is used as source of drinking water, the water quality must meet the standard on first grade. However, the Lake Rawa Pening water quality monitoring should be conducted periodically to ensure that the water quality is still fit for the use and meet the quality standards required. Based on these problems, the purposes of this study were to determine the status of water quality of the lake of Rawa Pening and to evaluate the possibility of the Lake Rawa Pening water as a source of drinking water in accordance to Goverment Regulation Number 82 of 2001.

\section{STUDY METHODS}

The research was conducted in the Lake Rawa Pening, district of Semarang, Central Java Indonesia during three months of July, August, and September 2016. The study was undertaken by taking the water samples monthly in seven sites in the stagnant water that representing the variation of characteristic sites in Lake Rawa Pening, including 1) mouth area of the Torong River and the Galeh River, 2) tourism area of Bukit Cinta, 3) area of Pening spring water, 4) mouth area of the Sraten River, 5) mouth area of Muncul and the Legi River, 6) mouth area of the Kedungringin River, and 7) outlet area (canal of the Tuntang River). The sampling scheme was illustrated in Figure 1.

The data obtained were including measurement of insitu parameter for each site (temperature, $\mathrm{pH}$, dissolved oxygen) and ex-situ parameters from laboratory analyses of each sample as listed in Government Regulation No. 82 of 2001 including physical, microbiological, chemical (organic and an organic), and radioactivity parameters. Physical parameter measured were total suspended solid, total dissolved solid. Microbiological included total coliform and faecal coliform. An organic chemical were $\mathrm{PO}_{4}-\mathrm{P}$, $\mathrm{NO}_{3}-\mathrm{N}, \mathrm{NH}_{3}-\mathrm{N}, \mathrm{NO}_{2}-\mathrm{N}, \mathrm{SO}_{4}$, free cloride, $\mathrm{H}_{2} \mathrm{~S}$ and metals including $\mathrm{Ar}, \mathrm{Co}, \mathrm{Ba}, \mathrm{Se}, \mathrm{Cd}, \mathrm{Cr}, \mathrm{Cu}, \mathrm{Fe}, \mathrm{Bo}, \mathrm{Mn}, \mathrm{Hg}, \mathrm{Zn}$, $\mathrm{Cl}$, Cyanide, and Fluoride. Whereas organic chemicals $\mathrm{Cl}$, Cyanide, and Fluoride. Whereas organic chemicals in-

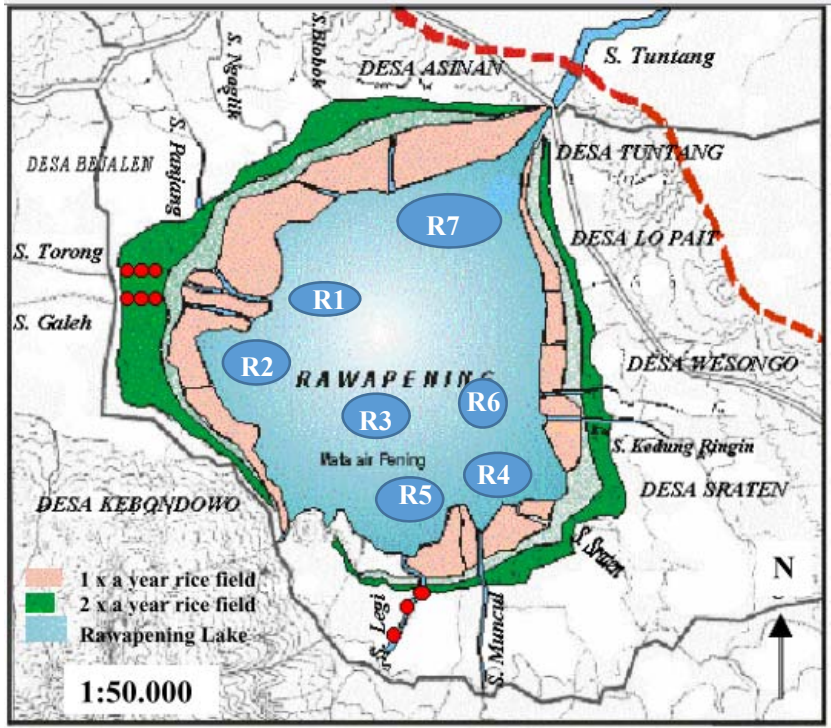

LEGEND

R1 : mouth area of the Torong River and the Galeh River

$\mathrm{R} 2$ : tourism area of Bukit Cinta

R3 : area of Pening spring water

R4 : mouth area of the Sraten River

R5 : mouth area of the Legi River and the Muncul River

R6 : mouth area of the Kedungringin River

R7 : area of outlet (canal of the Tuntang River)

Fig. 1. Sampling points (R1-R7) in Lake Rawa Pening; source: own elaboration

cluded oil/fat, detergent, phenol, BHC $(1,2,3,4,5,6$ hexachlorocyclohexane (benzene hexachloride), aldrin/ dieldrin, chlordane, DDT (dichlorodiphenyltrichloroethane), heptachlor, lindane, methoxyctor, endrin and toxaphan. Radioactivities were including gross A and gross B.

The water samples from each station was taken out from each sites during the day from 10.00 to $13.00 \mathrm{pm}$ using water sampler on the surface of the water (depth 20 $\mathrm{cm})$ as much as 2 liters and placed on the sample bottles. The sample bottle was sealed and placed in a dark environment at a constant temperature range of $4-10^{\circ} \mathrm{C}$ to avoid contamination and light and temperature impact. Every sampling time, we collected 3 replicates samples. Water samples from the field were analysed in the laboratory to determine their concentration based on APHA standards [APHA 1992].

The result data were analysed descriptively by comparing with applicable regulations based on Government Regulation No 82 of 2001 to evaluate whether they are meeting the requirement as a source of drinking water or not. The water quality status was performed using Storet method [ESTA et al. 2016] stated in Minister of Environment Decree No. 115 of 2003 represented in a Storet index. The data measured of each water quality parameter which calculated to find the minimum, maximum and average value based on 3 over period time of measurements.

Determination of water quality status using the Storet method is carried out by the following steps:

- compare the measured data of each parameter to the standard based on required water class;

- if the measured results meet the standard (measurement results lower than the standard) then given a score of 0 ; 
- if the measured results do not meet the standards (measurement results higher than the standards) then given a score according to the parameter group and the amount of data. Based on CANTER [1977] for $<10$ amount of data, the scoring system of parameters are as follows:

- physical: $\max -1, \min -2$, mean -3 ,

- chemical: $\max -2$, min -2 , mean -6 ,

- biological: $\max -3$, min -3 , mean -9 .

Whereas for $>10$ amount of data, the scoring system of parameters are as follow :

- physical: $\max -2, \min -2$, mean -6 ,

- chemical: $\max -4, \min -4$, mean -12 ,

- biological: $\max -6$, $\min -6$, mean -18 .

- the total negative number of all parameters is calculated and they are used to determine the score; the range of obtained total score are used to determine the level of water quality as well as the water status based on U.S. EPA [1972] into four classes as given in Table 1.

Table 1. Water quality level and water status based on Storet index

\begin{tabular}{|c|c|c|c|}
\hline No & $\begin{array}{c}\text { Total scores / } \\
\text { Storet index }\end{array}$ & Water quality level & Water status \\
\hline 1 & 0 & very good & no polluted \\
\hline 2 & {$[-10 ;-1]$} & good & mild pollution \\
\hline 3 & {$[-30 ;-11]$} & moderate & moderate polluted \\
\hline 4 & $>-31$ & bad & heavily polluted \\
\hline
\end{tabular}

Source: U.S. EPA [1972].

\section{RESULTS AND DISCUSSION}

In order to improve the health of society, it is necessary to be carried out water quality monitoring intensively and continuously. The quality of water used by the people must meet health requirements in order to avoid health problems. The terms of water quality related to health need to be adapted to technological developments and health efforts today's society. In relation to that, it needs to be set back the requirements and water quality control with the Minister of Health Regulation. In the regulation of clean water, requirements must meet quality standards based on the parameters of physics, chemistry, microbiology, as well as radioactivity. The water quality data were compared with standard water quality based on Government Regulation Number 82 of 2001. The data were determined using stored index to evaluate the water quality status.

The results showed that the water quality of Lake Rawa Pening was not meet the requirement for the source of drinking water based on physical, chemical and microbiological parameters except for radioactivity parameter. During this study, the result showed that there were 13 parameters that exceeded the water quality standard of grade I. They were total suspended solids (TSS), biological oxygen demand (BOD), chemical oxygen demand (COD), orthophosphate $\left(\mathrm{PO}_{4}-\mathrm{P}\right)$, As, $\mathrm{Se}, \mathrm{Cd}, \mathrm{Mn}, \mathrm{Cu}, \mathrm{Pb}, \mathrm{H}_{2} \mathrm{~S}$, faecal coliform, and total coliform (Tab. 3).

Physically clean water should be clear, colourless, odourless, and tasteless. Lake Rawa Pening water was greenish brown that indicates contain high organic matter and silt as well as high concentration of TSS. This was caused by high sediment load into the lake which was approximately $10.42 \cdot 10^{6} \mathrm{~kg} \cdot \mathrm{year}^{-1}$ [HENNY, HANDOKO 2016]. The concentration of TSS during observation range from $140.9-242.0 \mathrm{mg} \cdot \mathrm{dm}^{-3}$. The high content of TSS was in R4 (mouth of the Sraten River) - Table 2. It seems that the Sraten River contributed to sediment load that also contain high nutrient load into Lake Rawa Pening. Total suspended substances usually consist of organic and inorganic substances floating in the water resulted in the water become not clear. The high of TSS will also consume oxygen to breakdown the organic materials.

Organic chemicals in the water could be the form of insecticides and herbicides, volatile organic chemicals (organic chemicals evaporate absolute) harmful substances/toxic and oxygen bonding agent. Organic chemicals in drinking water can be divided into three categories. Category 1 is the chemicals that may be carcinogens for humans. Category 2 chemical is not a carcinogen to human nature. Category 3 is a chemical that can cause a chronic disease with no facts carcinogen. All kinds of organic che-

Table 2. Measurement of water quality of Lake Rawa Pening (July-September 2016) compared to water quality standard

\begin{tabular}{|c|c|c|c|c|c|c|c|c|c|c|}
\hline \multirow{2}{*}{ Parameter } & \multirow{2}{*}{$\begin{array}{c}\text { Measurement } \\
\text { unit }\end{array}$} & \multicolumn{7}{|c|}{ Sampling points } & \multirow{2}{*}{ Mean } & \multirow{2}{*}{$\begin{array}{c}\text { Water quality } \\
\text { standard of grade } 1\end{array}$} \\
\hline & & R1 & R2 & R3 & $\mathrm{R} 4$ & R5 & R6 & R7 & & \\
\hline TSS & $\mathrm{mg} \cdot \mathrm{dm}^{-3}$ & 162.9 & 195.6 & 218.8 & 242.1 & 174.4 & 201.1 & 140.9 & 190.8 & 50 \\
\hline BOD & $\mathrm{mg} \cdot \mathrm{dm}^{-3}$ & 3.8 & 4.8 & 3.7 & 3.6 & 4.0 & 4.9 & 4.2 & 4.1 & 2 \\
\hline COD & $\mathrm{mg} \cdot \mathrm{dm}^{-3}$ & 22.1 & 24.5 & 26.6 & 25.4 & 25.9 & 29.2 & 26.2 & 25.7 & 10 \\
\hline $\mathrm{PO}_{4}-\mathrm{P}$ & $\mathrm{mg} \cdot \mathrm{dm}^{-3}$ & 0.200 & 0.200 & 0.132 & 0.200 & 0.200 & 0.200 & 0.130 & 0.200 & 0.2 \\
\hline As & $\mathrm{mg} \cdot \mathrm{dm}^{-3}$ & 0.119 & 0.139 & 0.130 & 0.129 & 0.160 & 0.160 & 0.180 & 0.146 & 0.05 \\
\hline $\mathrm{Se}$ & $\mathrm{mg} \cdot \mathrm{dm}^{-3}$ & 0.029 & 0.032 & 0.017 & 0.028 & 0.010 & 0.010 & 0.004 & 0.018 & 0.01 \\
\hline $\mathrm{Cd}$ & $\mathrm{mg} \cdot \mathrm{dm}^{-3}$ & 0.007 & 0.008 & 0.015 & 0.016 & 0.020 & 0.020 & 0.010 & 0.013 & 0.01 \\
\hline $\mathrm{Mn}$ & $\mathrm{mg} \cdot \mathrm{dm}^{-3}$ & 0.157 & 0.200 & 0.377 & 0.334 & 0.250 & 0.240 & 0.210 & 0.253 & 0.1 \\
\hline $\mathrm{Cu}$ & $\mathrm{mg} \cdot \mathrm{dm}^{-3}$ & 0.009 & 0.013 & 0.021 & 0.019 & 0.010 & 0.010 & 0.010 & 0.013 & 0.02 \\
\hline $\mathrm{Pb}$ & $\mathrm{mg} \cdot \mathrm{dm}^{-3}$ & 0.025 & 0.023 & 0.032 & 0.037 & 0.020 & 0.027 & 0.020 & 0.026 & 0.03 \\
\hline $\mathrm{H}_{2} \mathrm{~S}$ & $\mathrm{mg} \cdot \mathrm{dm}^{-3}$ & 0.005 & 0.008 & 0.006 & 0.005 & 0.010 & 0.010 & 0.010 & 0.006 & 0.001 \\
\hline Faecal coliform & ind. per $100 \mathrm{~cm}^{3}$ & 172.667 & 203.667 & 205.667 & 248.000 & 242.000 & 167.330 & 212.00 & 207.333 & 100 \\
\hline Total coliform & ind. per $100 \mathrm{~cm}^{3}$ & $5,500.00$ & $6,400.00$ & $6,133.33$ & $6,400.00$ & $6,166.67$ & $6,800.00$ & $5,933.33$ & $6,190.48$ & 1000 \\
\hline
\end{tabular}

Explanations: R1-R7 = sampling points as in Figure 1.

Source: own study. 


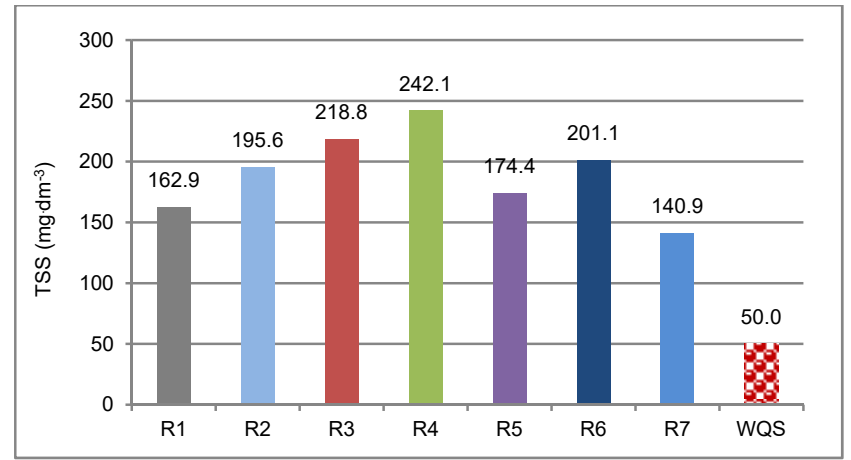

Fig. 2. Concentration of total suspended solids (TSS) in each sampling points (R1-R7) in Lake Rawa Pening compared to water quality standard (WQS); R1-R7 as in Fig. 1; source: own study

mical parameters in the water of Lake Rawa Pening were still below the standard of water quality.

Inorganic chemicals include metals, reactive substances, harmful substances and toxic as well as the degree of acidity $(\mathrm{pH})$. The presence of heavy metals is also one im-
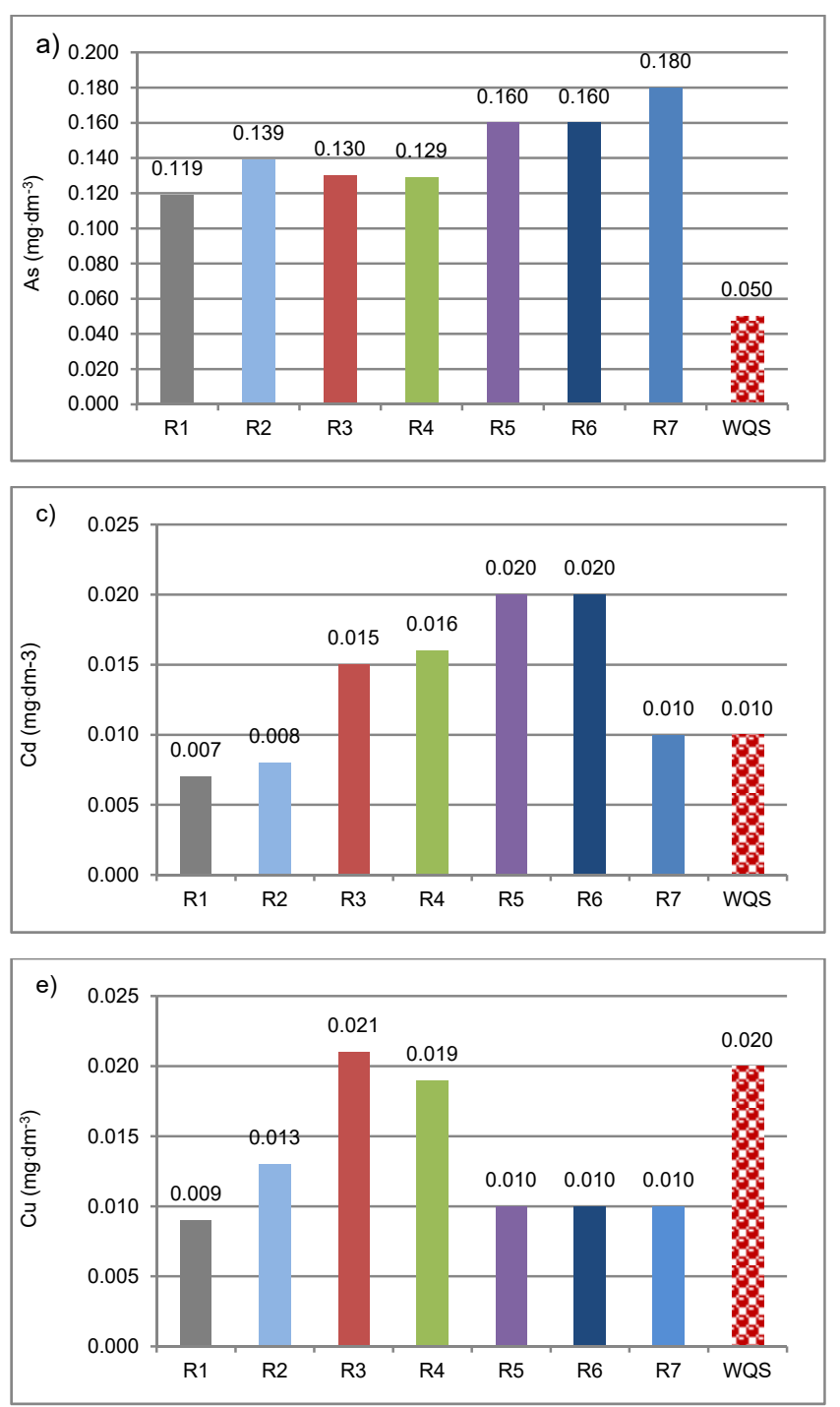

portant parameter to examine the level of pollution. Heavy metal contamination is generally caused by various types of waste, domestic, industrial, agricultural, and mining activities. The main source of heavy metal contamination in the water usually comes from river flow that enters the lake/reservoir. Lake Rawa Pening also has 6 heavy metals contaminated and the concentration has exceeded the water quality standard of grade I. They were arsenic (As), selenium $(\mathrm{Se})$, cadmium $(\mathrm{Cd})$, lead $(\mathrm{Pb})$, copper $(\mathrm{Cu})$, and manganese $(\mathrm{Mn})$ - Figure 3.

The high concentrations of metals in the lake due to the location of the Lake Rawa Pening is surrounded by urban areas with various activities like domestic, industrial, agricultural, and mining is inside the area of lake catchment [SOEWANDITA 2017]. Administratively, the catchment of Rawa Pening consisted of 16 rivers that flow into Lake Rawa Pening covering 72 villages spread over 11 sub-districts including in the Semarang and Salatiga District up to 29,864.54 hectares. Under these conditions, the pollutant brought by river will be accumulated in the Lake Rawa Pening.
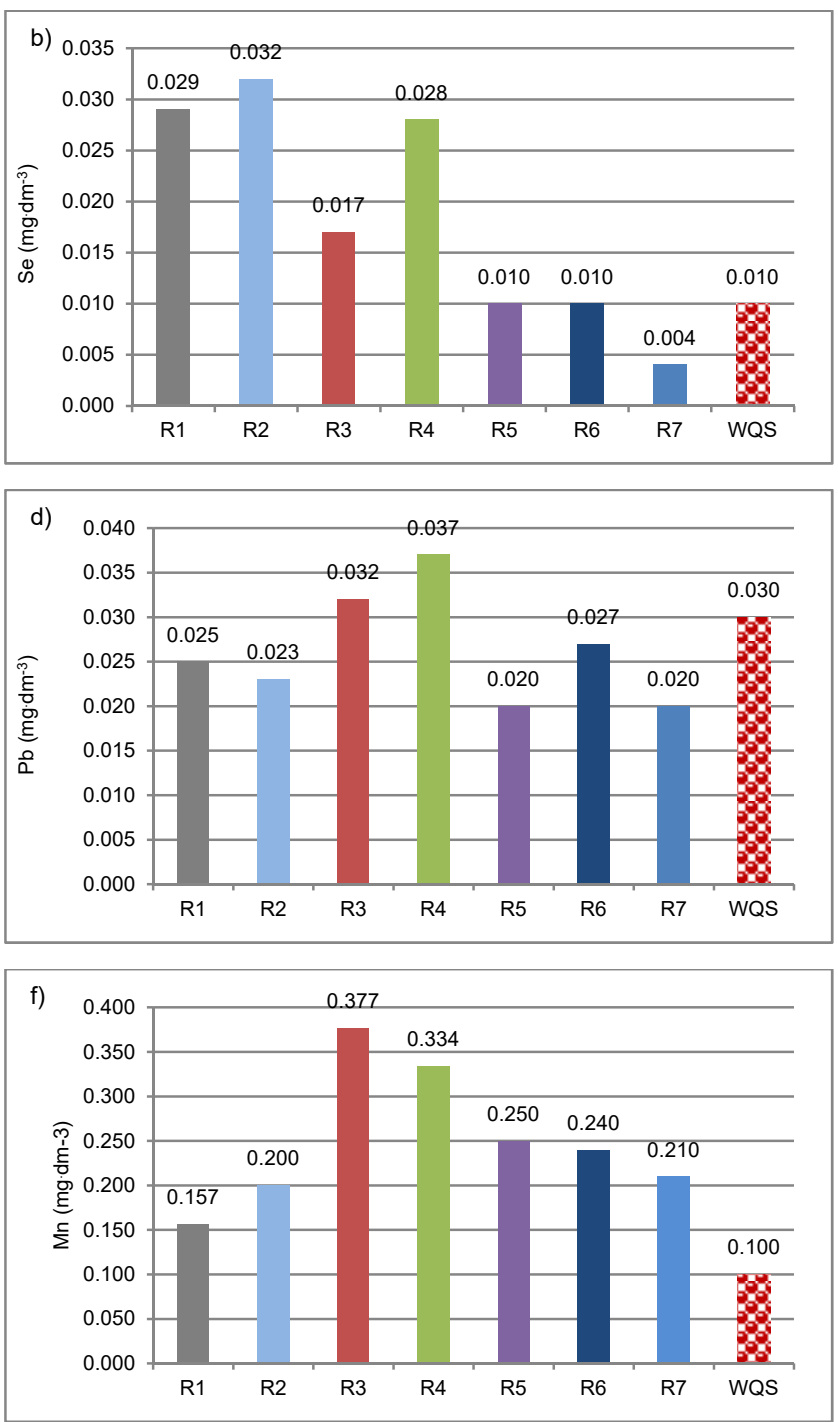

Fig. 3. Concentration of heavy metal in each sampling points (R1-R7) in Lake Rawa Pening compared to water quality standard (WQS) as in Fig. 1; a) As, b) Se, c) Cd, d) Pb, e) Cu, f) Mn; R1-R7 as in Fig. 1; source: own study 
Chronic arsenic is the element causing an acute reaction for humans. These compounds can undergo bioaccumulation and can cause poisoning. Arsenic levels in aquatic ecosystems that can damage chlorophyll and algae can be deadly. In waters intended for drinking water purposes, arsenic levels should not exceed $0.05 \mathrm{mg} \cdot \mathrm{dm}^{-3}$. The concentration of arsenic in the Lake Rawa Pening was very high up to $0.119-0.16 \mathrm{mg} \cdot \mathrm{dm}^{-3}$, exceeded the water standard. This contamination continues to grow in line with increased effort exploring a variety of natural sources where arsenic contained therein. Therefore some countries, such as Japan and Germany in 1993 has changed the maximum allowable limits for the content of arsenic in the water of 0.05 becomes $0.01 \mathrm{mg} \cdot \mathrm{dm}^{-3}$, while for Indonesia and other Asian countries the figure is still $0.05 \mathrm{ppm}$.

Selenium occurs naturally and dispersed in the environment, both natural processes and human activities. In the waters of selenium ( $\mathrm{Se}$ ) is in the form of insoluble in water but are absorbed into particulates. Levels of selenium in natural fresh waters varies between $<0.1$ and $5 \mu \mathrm{g} \cdot \mathrm{dm}^{-3}$. Based on Government Regulation No. 82 of 2001, the maximum levels of Se for drinking water is 0.01 $\mathrm{mg} \cdot \mathrm{dm}^{-3}$. The concentration of Selenium in the Lake Rawa Pening ranged from 0.004 to $0.032 \mathrm{mg} \cdot \mathrm{dm}^{-3}$ (Fig. 3f). The highest levels was in the mouth area of Torong and Galeh River (R1), area of Bukit Cinta tourism resort (R2) and Pening spring water (R3), and the mouth area of Legi and Muncul River (R4). The highest of selenium was in the mouth area of Torong and Galeh River (R1) because they were passing through urban areas where the waste was carried by runoff flow away from the human activities into the river, and then further into the lake.

Cadmium $(\mathrm{Cd})$ is a heavy metal that is normally found in soil and water in the lower levels. Cadmium comes from several sources, namely natural resources, mining, and industry. The volcano is the largest source of cadmium naturally. The high concentration of metals $\mathrm{Cd}$ and $\mathrm{Pb}$ due to the location of Lake Rawa Pening surrounded by urban areas with various industrial activities. Cadmium is a manufacturing industry lead waste into the lake through the river. Cadmium is a toxic substance that causes chronic poisoning in humans, then the maximum level permitted in the water is $0.01 \mathrm{mg} \cdot \mathrm{dm}^{-3}$ [Government Regulation Number 82 of 2001].

The use of lead $(\mathrm{Pb})$ is the largest in the battery industry, vehicles such as metallic lead and its components. Lead is used in gasoline for vehicles, paints, and pesticides. Contamination of $\mathrm{Pb}$ can occur in the air, water, and soil. The water body that has conceded the excessive compounds or ions of $\mathrm{Pb}$ will cause death to the aquatic biota. The maximum level of $\mathrm{Pb}$ contents allowed in water is $0.03 \mathrm{mg} \cdot \mathrm{dm}^{-3}$. The content of $\mathrm{Pb}$ in most sites was on the threshold of $0.03 \mathrm{mg} \cdot \mathrm{dm}^{-3}$ except in sites of R4 and R5 up to 0.032 $\mathrm{mg} \cdot \mathrm{dm}^{-3}$ and $0.037 \mathrm{mg} \cdot \mathrm{dm}^{-3}$. The location of sites $\mathrm{R} 4$ and R5 are the inlet area so that the concentration of domestic wastewater and vehicle emissions higher than in the other sites. Kind of fish in Lake Rawa Pening such as tilapia had already contained $\mathrm{Pb}$ up to $0.18 \mathrm{mg} \cdot \mathrm{kg}^{-1}$ [HIDAYAH et al. 2012]. The presence of $\mathrm{Pb}$ heavy metal content in fish due to heavy metals can be absorbed by fish through the food chain. According to the WHO limit the intake of foods that contain heavy metals, $\mathrm{Pb}$ is $0.2-0.3 \mathrm{mg} \cdot \mathrm{day}^{-1}$ per person. Agricultural fertilizers, especially phosphate fertilizers containing heavy metals $\mathrm{Pb}$ between 5 to $156 \mathrm{~g} \cdot \mathrm{kg}^{-1}$ and $7 \mathrm{~g} \cdot \mathrm{kg}^{-1}$ of Cd for neutral land [HIDAYAT 2015]. If fertilizer is used continuously with a high dose and intensity may increase $\mathrm{Pb}$ and $\mathrm{Cd}$ provided in a land so that when the water runoff passing through the agricultural area can increase the concentration of $\mathrm{Pb}$ and $\mathrm{Cd}$ in the waters. The presence of heavy metals deposited in the sediment will be a negative impact on the organisms living in the river bottom like mussels and shrimp and if consumed can be harmful to health and it will also have an impact on humans who use the water for their domestic needs.

Phosphorus is the key elements necessary for the growth of plants and animals [HORNE, GOLDMAN 1994]. Phosphates exist in three forms: orthophosphate, metaphosphate (or polyphosphates) and organic phosphates are each tied in phosphorus compounds with different chemical composition. Phosphate exists in the body of living organisms and plants/animals. Furthermore, the death organisms will decompose to release orthophosphate in ionic form. Orthophosphate is also produced by the natural process of rock weathering results, but human activities such as waste disposal and from runoff without passing through the area of agriculture can be a source of this $\mathrm{PO}_{4}-\mathrm{P}$ in water. Therefore phosphorus tends to be nutrient limiting growth and play a role in the Krebs cycle and the constituent DNA. Therefore, phosphate will stimulate the growth of plankton and aquatic plants as primary producers in aquatic ecosystems.

The high orthophosphate indicated that the nutrient of $\mathrm{P}$ in Lake Rawa Pening was too high. The forms of phosphate are present in living organisms and plants/animals and the decaying plants and animals will release orthophosphate ion $\left(\mathrm{PO}_{4}-\mathrm{P}\right)$. The orthophosphate $\left(\mathrm{PO}_{4}-\mathrm{P}\right)$ is a soluble phosphate which naturally is produced by the natural process of rock weathering results, but human activities such as waste disposal and runoff passing through the area of agriculture can be a source of $\mathrm{PO}_{4}-\mathrm{P}$ in water. The use of agricultural fertilizers in the catchment area that enters the lake through rivers also increases $\mathrm{PO}_{4}-\mathrm{P}$ concentration in the lake. Input of phosphate $(\mathrm{P})$ of the catchment area to Lake Rawa Pening was up to $10.32 \mathrm{mg} \cdot \mathrm{s}^{-1}$, and output was up to $6.71 \mathrm{mg} \cdot \mathrm{s}^{-1}$ (Fig. 4), so it could be said that Lake Rawa Pening served as a storage of $\mathrm{P}$ as much as 64.9\% [PIRANTI et al. 2016]. This means that the lake played as a source (as a sink) of phosphate to undergo resuspension become $\mathrm{PO}_{4}-\mathrm{P}$ when conditions in the bottom waters are alkaline [SMOLDERS et al. 2006].

Plankton is the foundation of the food chain. Initially, this increased productivity will lead to an increase in fish populations and biodiversity of the whole system. But while loading phosphate is increasing, there will be a build-up of phosphates in lakes or surface water ecosystems resulting in eutrophication process characterized by the occurrence of the blooming of algae (phytoplankton) and aquatic plants [MEDUPIN 2011]. The presence of Phytoplankton dominating by Ceratium and some blue-green algae indicates the lake to be moderately rich in nutrients 


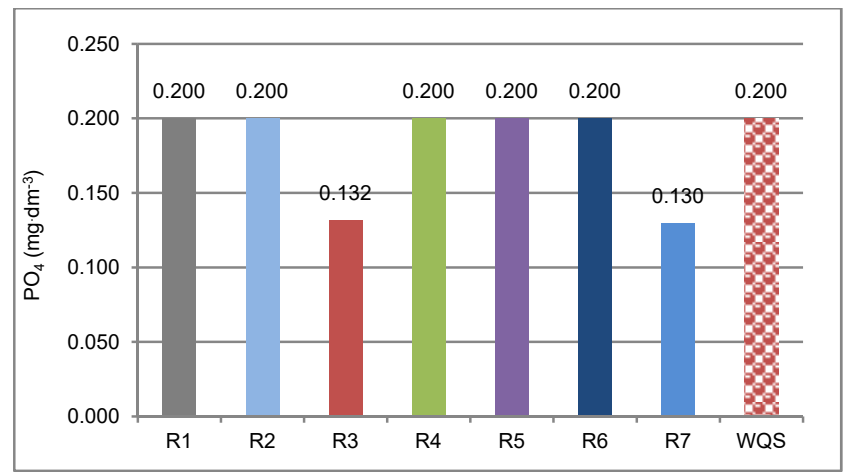

Fig. 4. Concentration of $\mathrm{PO}_{4}-\mathrm{P}$ in each sampling points (R1-R7) in Lake Rawa Pening compared to water quality standard; R1-R7 as in Fig. 1; source: own study

on the trophic state of mesotrophic-eutrophic. The presence of other minor species of Eudorina, Scenedesmus and Elakatothrix; Synedra and Cyclotella (diatom); Dinobryon, Sphaerocystis, Staurastrum spp., Cosmarium sp. and Tabellaria all indicated to be moderately rich in nutrients (mesotrophic) lake [SOEPROBOWATI et al. 2010] and the presence of Cyanophytes like Oscillatoria agardhii, Microcystis, Aphanizomenon, Chlorella and Anabaena were indicators of a nutrient-rich lake [MEDUPIN 2011].

Lake Rawa Pening eutrophication condition indicated by the growth of water hyacinth is very abundantly. The growth of water hyacinth in the lake Rawa Pening calculated by the addition of shoots per day for an average of 1,389 shoots per day [PIRANTI et al. 2016]. Water hyacinth growth fluctuated during the period 2000-2013, a significant growth of water hyacinth which occurred in 2005 and 2013. The vast percentage hyacinth cover approximately $25 \%$ in 2000 , increased to $65 \%$ in 2005 , decreased to $32 \%$ in 2009 and increased again to $45 \%$ in 2013 [TRISAKTI et al. 2012]. The magnitude of the increase in the area covered hyacinth because it is supported by the rapid growth of the water hyacinth. Therefore, because growth is so rapid that this plant can cover the entire surface waters, consequently the amount of light entering the water on the wane and all dissolved oxygen level will decrease and consequently. Water Hyacinth can also damage the surrounding environment and the cause of superficiality. This is because the dead water hyacinth will accumulate to the surface so that over time will become shallow waters, there because reducing the amount of water. However, the positive impact of the hyacinth is able to prevent the accumulation of heavy metals. Consuming fish continuously be harmful to for the body, because the freshwater fish when there is a heavy metal accumulation of heavy metals in the body increased over the long term. For that, we need the treatment, one with the water hyacinth plants. From the research, water hyacinth is able to absorb heavy metals in water [TOSEPU 2012].

A source of drinking water must be safe and guaranteed quality and quantity. If the water supply becomes contaminated, consumers can get sick. The most important parameter as an indicator of the quality of drinking water is total coliform bacteria not exceeding 1,000 per $100 \mathrm{~cm}^{3}$. In laboratories, total coliform is used as an indicator of pollu- tion of water by faeces, soil or other natural sources. While faecal coliform is an indicator of contamination of water by human or animal feces and should not exceed than 100 ind. per $100 \mathrm{~cm}^{3}$ (Fig. 5). The microbiological parameters used as a parameter to prevent microbial pathogens in drinking water. Coliform bacteria do not cause disease. However, their presence in drinking water indicates that disease-causing organisms (pathogens) may be present in the water system. With the presence of coliform bacteria in water with the amount range of 5,500-6,800 ind. per 100 $\mathrm{cm}^{3}$ (Fig. 6) had shown that the Lake Rawa Pening water could be categorized no feasible as a raw source of drinking water. Based on the Health Minister Regulation No. 419 of 1990 , the quality requirement of clean water should contain no coliform bacteria $\left(0\right.$ per $\left.100 \mathrm{~cm}^{3}\right)$.

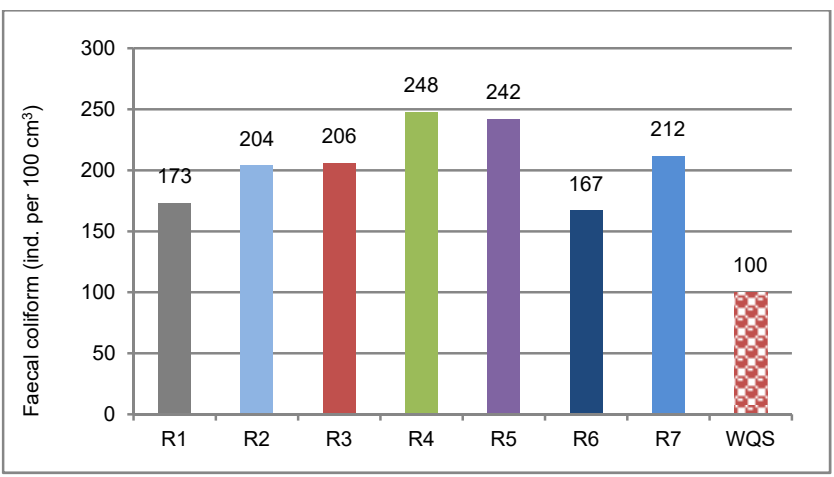

Fig. 5. Concentration of faecal coli in sampling points (R1-R7) in Lake Rawa Pening; R1-R7 as in Fig. 1, WQS = water quality standard; source: own study

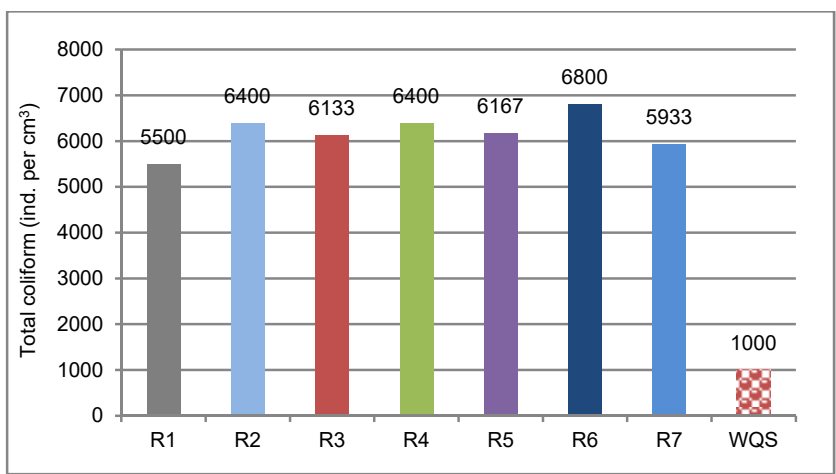

Fig. 6. Concentration of total coliform in sampling points (R1-R7) in Lake Rawa Pening; R1-R7 as in Fig. 1, WQS = water quality standard; source: own study

The high concentration of BOD and COD indicated that the content of organic and inorganic materials in the lake either suspended or dissolved was very high. These were due to the high material carried by the river flow into the lake and as a result of the decay of aquatic weeds in the lake as well as waste from fish farming using floating net.

Fish farming using floating net is suspected causing the high entry of organic matter especially the element of phosphorus into water bodies caused by pellet feeding to fish. High total phosphorus concentration (total-P) indicates that material organics that enter the waters are also high. Based on data of Department of Livestock and Fish- 
eries Semarang District during 2012 that the number of floating net operated in Lake Rawa Pening were up to 452 units [SAMUDRA et al. 2013]. Furthermore, the calculation of the carrying capacity reported that with the maximum amount of feed applied should be 1,084.80 tons of feed per year. In fact, the total feed given in Lake Rawa Pening was as much as $1,979.76$ tons per year. This amount was more than twice the provision of feed based on the capacity of phosphorus pollution load. This condition become worse with feed conversion ratio (FCR) of 1.83 was higher than commonly of 1.50 [SAMUDRA et al. 2012]. It gave a proof that the amount of feed given to fish in the Lake Rawa Pening was less efficient [ERLANIA et al. 2010]. This inefficient feeding could cause an excessive influx of organic material into the water causing pollution.

Chemical oxygen demand (COD) and biochemical oxygen demand (BOD) is a measure of the amount of organic matter in the waters. Waters with high COD and/or BOD values indicate that the water is polluted by organic matter [HORNE, GOLDMANN 1994]. COD is the need for oxygen for the chemical decomposition of organic matter. Oxygen depletion that occurs in the water column is strongly influenced by the concentrations of BOD and COD in the watershed [CROSS, SUMMERFELT 1987]. The high BOD/COD in the water column is caused by anoxic conditions at the bottom of the lake which illustrate the slow decomposition of organic matter in the bottom of the waters. The COD concentration in Lake Rawa Pening ranges from 22.12 to $29.18 \mathrm{mg} \cdot \mathrm{dm}^{-3}$ (Fig. 7). This has far exceeded grade I standard of $10 \mathrm{mg} \cdot \mathrm{dm}^{-3}$. Grade II water quality standard requires that the COD concentration not exceed $25 \mathrm{mg} \cdot \mathrm{dm}^{-3}$. Based on these provisions, Lake Rawa Pening water is not feasible if it is used as raw water for drinking water and recreational facilities. The BOD concentration of Lake Rawa Pening in all observation stations showed that it exceeded grade I (Fig. 8). The $\mathrm{BOD}_{5}$ concentration required for grade I standard is $2 \mathrm{mg} \cdot \mathrm{dm}^{-3}$. Therefore, based on the concentration of BOD, Lake Rawa Pening water was not suitable when used as a source of drinking water.

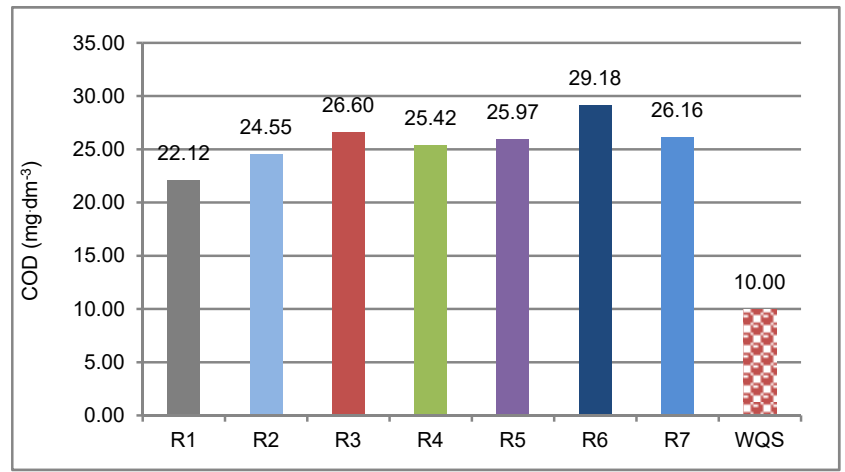

Fig. 7. Concentration of COD in sampling points (R1-R7) in Lake Rawa Pening; R1-R7 as in Fig. 1; source: own study

The dissolved oxygen during observation was fluctuated depend on the season. July was representing period of rainy season, whereas September was representing period of dry season. During dry season the river flow was very limited, even several rivers became dried. Usually during

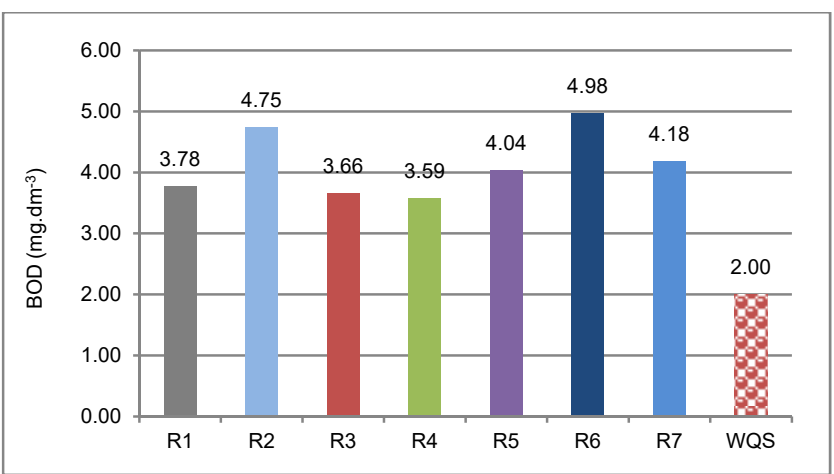

Fig. 8. Concentration of BOD in sampling points (R1-R7) in Lake Rawa Pening; R1-R7 as in Fig. 1; source: own study

this period the hydropower generator from Lake Rawa Pening will not being functioned because limited water. This condition will enhance organic material to decay indicated by lowest DO especially during dry season (September). However, overall the average DO concentrations were still above the standard DO concentration for fisheries $\left(>3 \mathrm{mg} \cdot \mathrm{dm}^{-3}\right)$ as regulated by the Government of Republic of Indonesia under Government Decree No. 82 of 2001 (Tab. 3).

Table 3. The dissolved oxygen (DO) concentration in sampling points in Lake Rawa Pening during observation

\begin{tabular}{|c|l|c|c|c|c|}
\hline \multirow{2}{*}{ No. } & \multicolumn{2}{|c|}{ Sampling point } & \multicolumn{4}{|c|}{ DO concentration $\left(\mathrm{mg} \cdot \mathrm{dm}^{-3}\right)$} \\
\cline { 3 - 6 } & & July & August & $\begin{array}{c}\text { Sep- } \\
\text { tember }\end{array}$ & average \\
\hline 1 & Torong and Galeh River & 5.2 & 4.3 & 4.4 & 4.3 \\
\hline 2 & Tourism area "Bukit Cinta" & 6.5 & 2.4 & 1.6 & 2.4 \\
\hline 3 & Spring water & 4.1 & 4.35 & 1.4 & 4.4 \\
\hline 4 & Sraten River & 3.5 & 4.6 & 1.4 & 4.6 \\
\hline 5 & Legi and Muncul River & 6.0 & 5.2 & 1.6 & 5.2 \\
\hline 6 & Kedungringin River & 5.7 & 5.45 & 5.6 & 5.5 \\
\hline 7 & outlet & 6.3 & 4.85 & 5.7 & 4.9 \\
\hline \multicolumn{2}{|l|}{ Average } & $\mathbf{5 . 3}$ & $\mathbf{4 . 5}$ & $\mathbf{3 . 1}$ & $\mathbf{4 . 5}$ \\
\hline
\end{tabular}

Source: own study.

The water bodies that have a high BOD will generally release the odour. The concentration range of COD in Rawa Pening during observation was 22.117-29.180 $\mathrm{mg} \cdot \mathrm{dm}^{-3}$ and BOD up to $3.6-4.9 \mathrm{mg} \cdot \mathrm{dm}^{-3}$. This range of those two parameters had already above the standard. This high concentration could be caused occurring the decomposition of organic waste anaerobically (without oxygen) that produce $\mathrm{NH}_{3}, \mathrm{H}_{2} \mathrm{~S}, \mathrm{CH}_{4}$. Consequently, the concentration of $\mathrm{H}_{2} \mathrm{~S}$ in the lake was already very high up to 0.005 to $0.1 \mathrm{mg} \cdot \mathrm{dm}^{-3}$ (Fig. 9) and has exceeded the first-grade water quality standard of $0.001 \mathrm{mg} \cdot \mathrm{dm}^{-3}$ and even the third grade of $0.002 \mathrm{mg} \cdot \mathrm{dm}^{-3}$.

Concentrations of hydrogen sulphide $\left(\mathrm{H}_{2} \mathrm{~S}\right)$ in Lake Rawa Pening already very high in all measurement locations ranged $0.005-0.1 \mathrm{mg} \cdot \mathrm{dm}^{-3}$ and has far exceeded the quality standard of class II and even class III (0.001 $\left.\mathrm{mg} \cdot \mathrm{dm}^{-3}\right)$. The highest concentration was in the mouth area of Legi and Muncul River (R5), mouth area of Kedungringin (R6), and the outlet area (R7) where the raw water of drinking water was taken (Fig. 9). Site of R5 is the inlet 


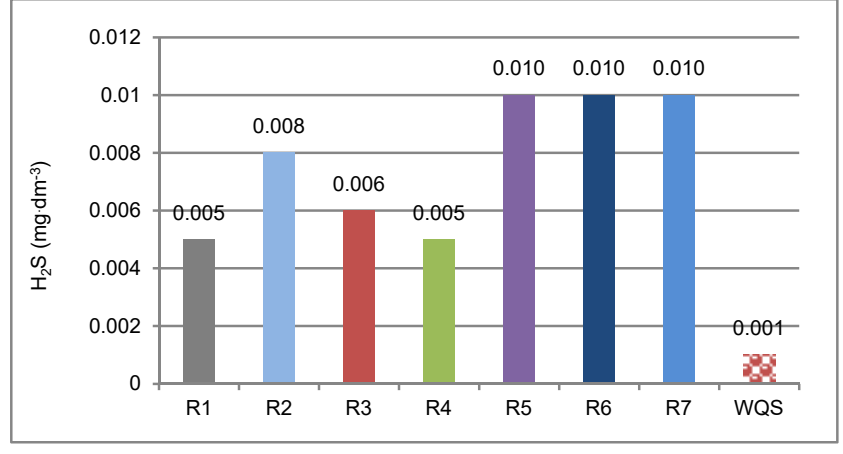

Fig. 9. Concentration of $\mathrm{H}_{2} \mathrm{~S}$ in each sampling (R1-R7) in Lake

Rawa Pening; R1-R7 as in Fig. 1; source: own study

area of the lake come from the Muncul River. In this area, there are locations that are used for tourism activities such as swimming pool and restaurant so that waste and sewage into the lake of decay that releases $\mathrm{H}_{2} \mathrm{~S}$ gas. The concentration of $\mathrm{H}_{2} \mathrm{~S}$ in Lake Rawa Pening was so high in all sampling sites. It showed that the process of anaerobic degradation of organic matter occurred in Lake Rawa Pening.

High concentration of radioactivity substance (gross-A and gross-B) can cause cell damage. Such damage may include death and changes in genetic composition. Cells that die can be replaced as long as not all the cells die, whereas genetic changes can cause diseases such as cancer or mutation of cells. However, the water of Lake Rawa Pening did not have the problem with the radioactive substances.

The level of water pollution is represented from the number of pollutant elements contained in these waters and is determined as the water quality standard. If the amount of pollutant has exceeded the standard requirement, it means that its existence can cause harm to living organisms that utilize the waters. The water quality status of Lake Rawa Pening during the observation were in heavily polluted in all sites based on the standard of grade 1 for source of drinking water. It was meant that the water was not meet the requirement as a source of drinking water.

The Storet index of each site of Lake Rawa Pening quality during period of July to September 2016 were showed in Table 3 . The index showed that the water quality status in all sampling locations had was in heavily polluted (Tab. 4). It was supporting by 13 parameters were exceed the water quality standard of grade 1.

\section{CONCLUSIONS}

Physically, chemically and microbiologically, there were 13 parameters of Lake Rawa Pening water quality that exceeded the standard on first grade. They were TSS, BOD, COD, $\mathrm{PO}_{4}-\mathrm{P}, \mathrm{As}, \mathrm{Se}, \mathrm{Cd}, \mathrm{Mn}, \mathrm{Cu}, \mathrm{Pb}, \mathrm{H}_{2} \mathrm{~S}$, faecal coliform, total coliform. Therefore, the water of Lake Rawa Pening did not meet the requirements as a source of drinking water and it should not be used for it without treatment.

\section{ACKNOWLEGEMENT}

Thanks to UNSOED the Directorate General of Higher Education Research and Technology of Indonesia for funding this project through the Fundamental Research Scheme with contract Number of Kept.1918/UN23.14/PN.01.00/2016 March 2, 2016. Give special thanks also to Dr. Norman Arie Prayoga, S.Pi. for early review for this article.

\section{REFERENCES}

APHA 1992. Standard methods for examination of water and wastewater. 18th ed. New York. American Public Health Association, American Water Works Association (AWWA), Water Environment Federation (WEF).

CANTER L.W. 1977. Environmental impact assessment. New York, Oklahoma. McGraw-Hill Companies. ISBN 007009764X pp. 331.

ERlania R., Prasetio A.B., Haryadi H. 2010. Dampak Manajemen Pakan Dari Kegiatan Budidaya Ikan Nila (Oreochromis niloticus) Di keramba jaring apung terhadap kualitas perairan danau Maninjau [Impact of feed management from cultivation of tilapia (Oreochromis niloticus) in floating net cages on the quality of Maninjau lake waters]. Prosiding Forum Inovasi Teknologi Akuakultur p. 621-631.

Esta K.A., Suarya P., Suastuti D.A. 2016. Penentuan Status Mutu Air Tukad Yeh Poh Dengan Metode Storet [Determination of Tukad Yeh Poh water quality status with the Storet method]. Jurnal Kimia. No. 10 (1) p. 65-67.

Hidayah A.M.L., Purwanto, Soeprobowati R. 2012. Kandungan Logam Berat pada Air, Sedimen dan Ikan Nila (Oreochromis niloticus Linn) [Heavy metal content in water, sediment and tilapia (Oreochromis niloticus Linn.). Prosiding Seminar Nasional Pengelolaan Sumberdaya Alam dan Lingkungan. 11.09.2012 Semarang p. 95-101.

HIDAYAT B. 2015. Remediasi tanah tercemar logam berat dengan menggunakan biochar [Remediation of heavy metal polluted soils using Biochar]. Jurnal Pertanian Tropik. Vol. 2. No. 1 (7) p. 31-41.

Horne A.J., Goldman C.R. 1994. Lymnology. $2^{\text {nd }}$ ed. McGraw Hill, Inc. New York.

Table 4. Water quality status based on water quality standard of grade 1

\begin{tabular}{|c|c|c|c|c|c|c|c|c|c|c|c|c|c|c|c|}
\hline \multirow{2}{*}{$\begin{array}{c}\text { Sampling } \\
\text { point }\end{array}$} & \multicolumn{13}{|c|}{ Storet index on each parameter } & \multirow[b]{2}{*}{ Total } & \multirow[b]{2}{*}{ Water status } \\
\hline & TSS & BOD & COD & $\mathrm{PO}_{4}-\mathrm{P}$ & As & $\mathrm{Se}$ & $\mathrm{Cd}$ & $\mathrm{Mn}$ & $\mathrm{Cu}$ & $\mathrm{Pb}$ & $\mathrm{H}_{2} \mathrm{~S}$ & $\begin{array}{c}\text { faecal } \\
\text { coli }\end{array}$ & $\begin{array}{c}\text { total } \\
\text { coliform }\end{array}$ & & \\
\hline R1 & -10 & -20 & -20 & -4 & -20 & -20 & -4 & -20 & -4 & -4 & -20 & -30 & -30 & -206 & heavily polluted \\
\hline R2 & -10 & -20 & -20 & -4 & -8 & -8 & -16 & -20 & -4 & -4 & -20 & -30 & -30 & -194 & heavily polluted \\
\hline R3 & -10 & -20 & -20 & -4 & -20 & -20 & -20 & -20 & -16 & -16 & -20 & -30 & -30 & -246 & heavily polluted \\
\hline $\mathrm{R} 4$ & -10 & -20 & -20 & -4 & -20 & -20 & -20 & -20 & -4 & -20 & -20 & -30 & -30 & -238 & heavily polluted \\
\hline R5 & -10 & -20 & -20 & -4 & -20 & -4 & -20 & -20 & -4 & -4 & -20 & -30 & -30 & -206 & heavily polluted \\
\hline R6 & -10 & -20 & -20 & -4 & -20 & -4 & -8 & -20 & -4 & -4 & -20 & -30 & -30 & -194 & heavily polluted \\
\hline R7 & -10 & -20 & -20 & -4 & -20 & -4 & -4 & -20 & -4 & -4 & -20 & -30 & -30 & -190 & heavily polluted \\
\hline
\end{tabular}

Explanations: R1-R7 = sampling points as in Figure 1.

Source: own study. 
MeduPIN C. 2011. Phytoplankton community and their impact on water quality: An analysis of Hollingsworth Lake, UK [online]. Journal of Applied Sciences and Environmental Management. Vol. 15. Iss. 2 p. 347-350. [Access 19.09.2018]. Available at: http://www.bioline.org.br/pdf?ja 11060

Piranti A.S., RAHAYU D.R.U.S., WaluYo G. 2016. Input of nutrient [nitrogen and phosphorus] from the catchment area into Rawapening Lake of Central Java. Proceeding International Basic Science 2016. Jember, Indonesia p. 50-51.

Piranti A.S., Rahayu D.R.U.S., Waluyo G. 2018. Nutrient Limiting Factor for Enabling Algae Growth of Rawapening Lake, Indonesia. Biosaintifika: Journal of Biology and Biology Education. Vol. 10. No. 1 p. 101-108.

SAMUdRa S.R., SoEProbowati T.R., Izzati M. 2013. Daya tampung Beban Pencemaran Fosfor Untuk Budidaya Perikanan Danau Rawa Pening. Laporan Penelitian [The capacity of the load of phosphorus pollution for Lake Rawa Pening aquaculture. Research report]. Prosiding Workshop Penyelamatan Ekosistem Danau. Rawa Pening Kementerian Lingkungan Hidup Bekerjasama dengan Universitas Diponegoro p. 134142.

SMOLDERS A.J.P., LAMERS L.P.M., LUCASSEN E.C.H.E.T., VAN DER VELDE G., ROELOFS J.G.M. 2006. Internal eutrophication: How it works and what to do about it - a review. Chemistry and Ecology. Vol. 22. No. 2 p. 93-111.

SNI 2008. Tata cara perencanaan unit paket instalasi pengolahan air. Standard Nasional Indonesia [The procedure for planning of water treatment plant package unit. Indonesian National Standard]. Panitia Teknik Bahan Konstruksi Bangunan dan Rekayasa Sipil melalui Gugus Kerja Lingkungan Permukiman pada Sub panitia Teknis Perumahan, Sarana, dan Prasarana, Badan Standarisasi Nasional (BSN). Indonesia
Soeprobowati T.R., Suedy S.W.A. 2010. Status Trofik Danau Rawa Pening dan Solusi Pengelolaannya [Trophic status of Lake Rawa Pening and its management solutions]. Jurnal Sains Dan Matematika. No. 18 p. 158-169.

SoewandiTA H. 2017. Studi Ekologi Lahan Koridor Sungai Dan Status Kualitas Penggunaan Lahan Di Wilayah Das Rawa Pening [Study of river corridor ecology and status of quality of land use in das Rawa Pening Region]. Jurnal Alami. Vol. 1. No. 1 p. 33-42.

Sulastri, HenNy C., Handoko U. 2016. Environmental condition and trophic status of Lake Rawa Pening in Central Java. Oseanologi dan Limnologi di Indonesia. Vol. 1(3) p. 23-38.

Tosepu R. 2012. Laju Penurunan Logam Berat Plumbum ( $\mathrm{Pb})$ Dan Cadmium (Cd) Oleh Eichornia Crassipes Dan Cyperus Papyrus [Rate of decrease in plumbum heavy metal $(\mathrm{Pb})$ and cadmium (Cd) by Eichornia crassipes and Cyperus papyrus]. Journal Manusia dan Lingkungan. Vol. 19. No. 1 p. 37-45.

Trisakti B., Suwargana N. CAhYono J.S. 2012. Pemanfaatan Data Penginderan Jauh Untuk Memantau Parameter Status Ekosistem Perairan Danau (Studi Kasus: Danau Rawa Pening) Di: Deteksi Parameter Geobiofisik dan Diseminasi Penginderaan Jauh [Utilization of remote sensing data to monitor parameters of lake aquatic ecosystem status (Case study: Lake Rawa Pening). In: Detection of geobiophysical parameters and remote sensing dissemination. Bidang Sumber Daya Wilayah Pesisir, Pusfatja-LAPAN p. 393-402.

U.S. EPA 1972. Water quality criteria. A report of the Committee on Water Quality Criteria. Washington, D.C. United States Environmental Protection Agency pp. 594.

WHO 2011. Guidelines for drinking-water quality. 4th ed. Geneva, Switzerland. World Health Organization. ISBN 978924 1548151 pp. 541.

\section{Agatha PIRANTI, Gentur WALUYO, Diana R.U.S. RAHAYU}

\section{Możliwość wykorzystania jeziora Rawa Pening jako źródła wody pitnej}

\section{STRESZCZENIE}

Woda jeziora Rawa Pening jest wykorzystywana jako źródło wody pitnej. Rozporządzenie rządu Indonezji nr 82 z 2001 r. o zarządzaniu jakością wody i kontroli zanieczyszczeń stwierdza, że woda jeziora powinna spełniać standardy jakości wody pierwszego stopnia i być klasyfikowana jako woda pozbawiona zanieczyszczeń. Celem badań była ocena jakości wody według indonezyjskich i międzynarodowych norm. Jakość wody oceniano w 7 stanowiskach jeziora trzykrotnie w ciągu 3 miesięcy. Mierzone parametry odpowiadały zawartym w rozporządzeniu nr 82 z 2001 roku. Wyniki analiz wykazały, że 13 parametrów przekracza dopuszczalne normy przewidziane dla 1 klasy czystości. Te parametry to: zawiesina całkowita (TSS), biochemiczne i chemiczne zapotrzebowanie na tlen (BOD, COD), fosforany, azotany, As, Se, Cd, Mn, $\mathrm{Cu}, \mathrm{Pb}, \mathrm{H}_{2} \mathrm{~S}$, bakterie $E$. coli i bakterie z grupy coli. Stan wód jeziornych określono jako silnie zanieczyszczone. Jakość wody jeziora Rawa Pening powinna ulec poprawie przez ograniczenie ładunku zanieczyszczeń doprowadzanych do jeziora wskutek działalności człowieka.

Słowa kluczowe: jezioro Rawa Pening, normy jakości wody, woda pitna, wskaźnik Storet 